\title{
ГЕНДЕРНІ ВІДМІННОСТІ ОСОБИСТІСНИХ ОСОБЛИВОСТЕЙ СТУДЕНТІВ З НЕПСИХОТИЧНИМИ ПСИХІЧНИМИ РОЗЛАДАМИ
}

\section{ВДНЗ «Буковинський державний медичний університет», Чернівці}

๑О. С. Юрценюк

РЕЗЮМЕ. Проблема спеціальної діагностики особистісних особливостей студентів є актуальною протягом всіх років навчання. В статті розглянуто гендерні відмінності особистісних особливостей та їх вплив на формування непсихотичних психічних розладів у студентів.

Мета - вивчення гендерних відмінностей особистісних особливостей студентів із непсихотичними психічними розладами та здорових студентів.

Матеріал і методи. Протягом 2015-2017 рр. з дотриманням принципів біоетики та деонтології ми провели суцільне комплексне обстеження 1235 студентів. Застосовані клінічний, клініко-психопатологічний, клінікоепідеміологічний, клініко-анамнестичний, експериментально-психологічний та статистичний методи. Вивчення особистісних особливостей проводили з використанням скороченого багатофакторного опитувальника особистості (СБОО), розробленого на підставі тесту MMPI (Minnesota Multiphasic Personality Inventory).

Результати. Виявлено, що в основній групі спостерігались вищі абсолютні значення фактично за всіма шкалами (р<0,005). Найвищі абсолютні показники у жінок встановлені за II (депресія) та VII (психастенія) шкалами $(59,32 \pm 0,97)$ та $(59,59 \pm 0,96)$ балів в основній групі $(\mathrm{N}=220)$ та $(44,22 \pm 0,37)$ та $(46,71 \pm 0,45)$ балів у порівняльній групі відповідно ( $\mathrm{N}=650)$. У чоловіків найвищі абсолютні показники були виявлені також за II та VII шкалами - $(62,90 \pm 1,56)$ та $(61,58 \pm 1,50)$ балів в основній групі $(\mathrm{N}=97)$ та $(45,46 \pm 0,52)$ та $(48,17 \pm 0,64)$ балів у порівняльній групі відповідно ( $\mathrm{N}=268)$. Істеричні особливості особистості достовірно частіше були характерними для дівчат з непсихотичними психічними розладами $16,36 \%$ та для $13,40 \%$ хлопців $(p<0,005)$.

Висновки. Серед студентів обох статей з непсихотичними психічними розладами достовірно частіше зустрічалися особи з депресивними, паранояльними, психастенічними та істеричними рисами особистості, що необхідно враховувати при ранній діагностиці та побудові психотерапевтичної програми для цього контингенту хворих.

КЛючОВІ СЛОВА: непсихотичні психічні розлади; міні-мульт; студенти.

Студентство - це особлива соціальна категорія, специфічна спільнота людей, об'єднаних інститутом вищої освіти. Студентство включає людей, що цілеспрямовано і систематично оволодівають знаннями та професійними вміннями, зайнятих, як передбачається, старанною навчальною працею. Як соціальна група, воно характеризується професійною спрямованістю, сформованістю ставлення до майбутньої професії [1].

Якщо вивчати студента як особистість, то вік 18-20 років - це період найактивнішого розвитку моральних і естетичних почуттів, становлення і стабілізації характеру i, що особливо важливо, оволодіння повним комплексом соціальних ролей дорослої людини - громадянських, професійно-трудових тощо. Перетворення мотивації, всієї системи ціннісних орієнтацій, з одного боку, та інтенсивне формування спеціальних здібностей у зв'язку з професіоналізацією - з іншого, виділяють цей вік як центральний період у становленні характеру й інтелекту [2, 3].

у дослідженнях, присвячених особистості студента, показується суперечливість внутрішнього світу, складність пошуку своєї самобутності й формування яскравої, висококультурної індивідуальності [1].

Студентський вік характеризується й тим, що в цей період досягають максимального розвитку ін- телектуальні і фізичні сили. Але нерідко одночасно проявляються «ножиці» між цими можливостями і їх справжньою реалізацією. Творчі можливості, які безперервно зростають, розвиток інтелектуальних і фізичних сил, які супроводжуються й розквітом зовнішньої привабливості, приховують в собі й ілюзії, що це зростання сил триватиме «вічно", що все життя ще попереду, і що всього задуманого можна легко досягти $[4,5]$.

Отже, проблема визначення індивідуальних особливостей студентів $\epsilon$ актуальною і в сучасному світі вимагає постійного вивчення факторів впливу на формування особистісних характеристик.

Мета - вивчення гендерних відмінностей особистісних особливостей студентів із непсихотичними психічними розладами та здорових студентів.

Матеріал і методи дослідження. Протягом 2015-2017 рр. з дотриманням принципів біоетики та деонтології ми провели суцільне комплексне обстеження студентів I-V курсів Вищого державного навчального закладу України «Буковинський державний медичний університет» (БДМУ) та студентів I-IV курсів Чернівецького національного університету.

Усіх студентів (1235 осіб) було поділено на дві групи - основну (I) та порівняльну (II). До основної групи увійшли 317 (25,67 \%) студентів, у яких було 
Огляди літератури, оригінальні дослідження, погляд на проблему, випадок з практики, короткі повідомлення діагностовано непсихотичні психічні розлади (НПР). Для верифікації клінічних особливостей НПР, в якості II порівняльної групи, було обстежено 918 (74,33 \%) студентів без НПР, практично здорових.

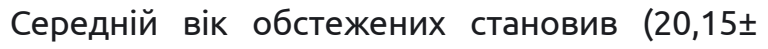
0,05) років. Гендерний розподіл був таким: 365 чоловіків та 870 жінок, відповідно 29,55 \% та 70,45 \%. Вибірка не мала суттєвих відмінностей за статевим і віковим складом, місцем мешкання, формою навчання. Обстеження проводили в міжсесійний період. Застосовані клінічний, клініко-психопатологічний, клініко-епідеміологічний, клініко-анамнестичний, експериментально-психологічний та статистичний методи.

Особистісні особливостівивчали з використанням скороченого багатофакторного опитувальника особистості (СБОО), розробленого на підставі тесту MMPI (Minnesota Multiphasic Personality Inventory) [6].

Результати й обговорення. У результаті проведеного дослідження виявлено, що в основній групі (студенти з НПР) спостерігались вищі абсолютні значення фактично за всіма шкалами ( $p<0,005)$. Найвищі показники встановлені за II (депресія) та VII (психастенія) шкалами - $(60,41 \pm 0,83)$ та $(60,20 \pm 0,81)$ балів в основній групі $(\mathrm{N}=317)$ та $(44,58 \pm 0,30)$ та $(47,14 \pm 0,37)$ балів у порівняльній групі відповідно (N=918) (табл. 1).

Таблиця 1. Абсолютні значення за шкалами СБОО в основній та порівняльній групах

\begin{tabular}{|c|c|c|c|c|c|c|c|}
\hline $\begin{array}{c}\text { Шкали } \\
\text { СБОО }\end{array}$ & $\begin{array}{c}\text { Середнє } \\
\text { значення в } \\
\text { основній групі }\end{array}$ & $\begin{array}{c}\text { Середнє } \\
\text { значення в } \\
\text { порівняльній } \\
\text { групі }\end{array}$ & $\begin{array}{c}\text { С95 \% ДІ в } \\
\text { основній групі }\end{array}$ & $\begin{array}{c}\text { Стандартна } \\
\text { похибка } \\
\text { середнього в } \\
\text { основній групі }\end{array}$ & $\begin{array}{c}\text { Стандартна } \\
+95 \text { \% ДІ в } \\
\text { порівнльній } \\
\text { групі }\end{array}$ & $\begin{array}{c}\text { похибка се- } \\
\text { реднього в } \\
\text { порівняльній } \\
\text { групі }\end{array}$ \\
\hline 1 & 54,97 & 49,19 & 56,18 & 0,61 & 49,62 & 0,22 & 0,005 \\
\hline 2 & 60,41 & 44,58 & 62,04 & 0,83 & 45,17 & 0,30 & 0,005 \\
\hline 3 & 56,84 & 48,06 & 58,21 & 0,70 & 48,70 & 0,33 & 0,005 \\
\hline 4 & 47,68 & 40,77 & 49,44 & 0,89 & 41,56 & 0,40 & 0,005 \\
\hline 6 & 56,59 & 44,84 & 58,18 & 0,81 & 45,49 & 0,33 & 0,005 \\
\hline 7 & 60,20 & 47,14 & 61,79 & 0,81 & 47,86 & 0,37 & 0,005 \\
\hline 8 & 52,22 & 46,48 & 53,43 & 0,62 & 47,12 & 0,33 & 0,005 \\
\hline 9 & 51,41 & 46,43 & 52,63 & 0,62 & 47,14 & 0,36 & 0,005 \\
\hline L & 46,20 & 49,89 & 47,09 & 0,45 & 50,42 & 0,27 & 0,005 \\
\hline F & 51,03 & 48,02 & 52,05 & 0,52 & 48,48 & 0,24 & 0,005 \\
\hline K & 46,22 & 50,26 & 47,08 & 0,44 & 50,77 & 0,26 & 0,005 \\
\hline
\end{tabular}

Як видно з таблиці 1, абсолютні показники за шкалою брехні (L) $-(46,20 \pm 0,45)$ в основній групі та $(49,89 \pm 0,27)$ балів у порівняльній групі - вказують на високий коефіцієнт щирості опитуваних.
Аналізуючи гендерні відмінності особистісних особливостей студентів можна зазначити, що достовірні відмінності характерні для жінок основної та порівняльної груп (табл. 2).

Таблиця 2. Абсолютні значення показників за шкалами СБОО, виявлені у жінок основної та порівняльної груп

\begin{tabular}{|c|c|c|c|c|c|c|c|}
\hline $\begin{array}{l}\text { Шкали } \\
\text { СБОО }\end{array}$ & $\begin{array}{c}\text { Середнє } \\
\text { значення в } \\
\text { основній групі }\end{array}$ & $\begin{array}{c}\text { Середнє } \\
\text { значення в } \\
\text { порівняльній } \\
\text { групі }\end{array}$ & $\begin{array}{c}\text { +95 \% ДІ в } \\
\text { основній групі }\end{array}$ & $\begin{array}{c}\text { Стандартна } \\
\text { похибка } \\
\text { середнього в } \\
\text { основній групі }\end{array}$ & $\begin{array}{c}\text { +95 \% ДІ в } \\
\text { порівняльній } \\
\text { групі }\end{array}$ & $\begin{array}{c}\text { Стандартна } \\
\text { похибка } \\
\text { середнього в } \\
\text { порівняльній } \\
\text { групі }\end{array}$ & $p$ \\
\hline 1 & 54,41 & 49,17 & 55,88 & 0,74 & 49,68 & 0,26 & 0,005 \\
\hline 2 & 59,32 & 44,22 & 61,22 & 0,97 & 44,94 & 0,37 & 0,005 \\
\hline 3 & 56,85 & 47,81 & 58,52 & 0,84 & 48,55 & 0,38 & 0,005 \\
\hline 4 & 46,90 & 40,52 & 49,03 & 1,08 & 41,46 & 0,48 & 0,005 \\
\hline 6 & 56,77 & 44,29 & 58,72 & 0,99 & 45,04 & 0,38 & 0,005 \\
\hline 7 & 59,59 & 46,71 & 61,48 & 0,96 & 47,59 & 0,45 & 0,005 \\
\hline 8 & 52,03 & 45,97 & 53,51 & 0,75 & 46,74 & 0,39 & 0,005 \\
\hline 9 & 51,85 & 46,56 & 53,31 & 0,74 & 47,40 & 0,42 & 0,005 \\
\hline $\mathrm{L}$ & 45,83 & 50,21 & 46,91 & 0,55 & 50,83 & 0,31 & 0,005 \\
\hline $\mathrm{F}$ & 50,73 & 48,00 & 51,91 & 0,60 & 48,54 & 0,28 & 0,005 \\
\hline $\mathrm{K}$ & 46,04 & 50,46 & 47,08 & 0,53 & 51,06 & 0,30 & 0,005 \\
\hline
\end{tabular}


Огляди літератури, оригінальні дослідження, погляд на проблему, випадок з практики, короткі повідомлення

Найвищі абсолютні показники у жінок встановлені за II (депресія) та VII (психастенія) шкалами - $(59,32 \pm 0,97)$ і $(59,59 \pm 0,96)$ балів в основній групі $(\mathrm{N}=220)$ та $(44,22 \pm 0,37)$ і $(46,71 \pm 0,45)$ балів у порівняльній групі відповідно ( $\mathrm{N}=650)$.
Як видно з таблиці 3, у чоловіків найвищі абсолютні показники були виявлені також за II (депресія) та VII (психастенія) шкалами - $(62,90 \pm 1,56)$ i $(61,58 \pm$ $1,50)$ балів в основній групі $(\mathrm{N}=97)$ та $(45,46 \pm 0,52)$ i $(48,17 \pm 0,64)$ балів у порівняльній групі $(N=268)$.

Таблиця 3. Абсолютні значення показників за шкалами СБОО, виявлені у чоловіків основної та порівняльної груп

\begin{tabular}{|c|c|c|c|c|c|c|c|}
\hline $\begin{array}{l}\text { Шкали } \\
\text { СБОО }\end{array}$ & $\begin{array}{c}\text { Середнє } \\
\text { значення в } \\
\text { основній групі }\end{array}$ & $\begin{array}{c}\text { Середнє } \\
\text { значення в } \\
\text { порівняльній } \\
\text { групі }\end{array}$ & $\begin{array}{c}\text { +95 \% ДІ в } \\
\text { основній групі }\end{array}$ & $\begin{array}{c}\text { Стандартна } \\
\text { похибка } \\
\text { середнього в } \\
\text { основній групі }\end{array}$ & $\begin{array}{c}\text { +95 \% ДІ в } \\
\text { порівняльній } \\
\text { групі }\end{array}$ & $\begin{array}{c}\text { Стандартна } \\
\text { похибка } \\
\text { середнього в } \\
\text { порівняльній } \\
\quad \text { групі } \\
\end{array}$ & $\mathrm{P}$ \\
\hline 1 & 56,24 & 49,24 & 58,36 & 1,07 & 50,06 & 0,42 & 0,005 \\
\hline 2 & 62,90 & 45,46 & 66,00 & 1,56 & 46,48 & 0,52 & 0,005 \\
\hline 3 & 56,79 & 48,68 & 59,25 & 1,24 & 49,93 & 0,63 & 0,005 \\
\hline 4 & 49,45 & 41,36 & 52,61 & 1,59 & 42,82 & 0,74 & 0,005 \\
\hline 6 & 56,19 & 46,19 & 58,95 & 1,39 & 47,43 & 0,63 & 0,005 \\
\hline 7 & 61,58 & 48,17 & 64,56 & 1,50 & 49,43 & 0,64 & 0,005 \\
\hline 8 & 52,64 & 47,70 & 54,80 & 1,09 & 48,88 & 0,60 & 0,005 \\
\hline 9 & 50,41 & 46,11 & 52,69 & 1,15 & 47,45 & 0,68 & 0,005 \\
\hline $\mathrm{L}$ & 47,04 & 49,12 & 48,61 & 0,79 & 50,14 & 0,52 & 0,005 \\
\hline $\mathrm{F}$ & 51,69 & 48,05 & 53,75 & 1,04 & 48,95 & 0,45 & 0,005 \\
\hline $\mathrm{K}$ & 46,65 & 49,77 & 48,16 & 0,76 & 50,74 & 0,49 & 0,005 \\
\hline
\end{tabular}

При порівнянні абсолютних показників за шкалами СБОО у хлопців основної групи (з НПР) визначені вищі показники за I, II, IV, VII шкалами, порівняно з дівчатами 3 тієї ж групи (див. табл. 1, 2). Як видно з даних, наведених у таблиці
4, депресивні радикали особистості зустрічалися достовірно частіше у жінок з НПР - 26,82 \%, та у 34,02 \% чоловіків тієї ж групи. Водночас ця особливість була притаманна лише 2,00 \% дівчат та 1,49 \% хлопців порівняльної групи.

Таблиця 4. Показники за шкалою депресії (D) СБОО, виявлені у жінок та чоловіків основної та порівняльної груп

\begin{tabular}{|c|c|c|c|c|c|c|c|c|}
\hline \multicolumn{9}{|c|}{ Жінки } \\
\hline \multirow{2}{*}{ показник в балах } & \multicolumn{2}{|c|}{ основна група (N=220) } & \multicolumn{2}{|c|}{ порівняльна група (N=650) } & \multirow{2}{*}{ t } & \multirow{2}{*}{ M1 } & \multirow{2}{*}{ M2 } & \multirow{2}{*}{$\mathrm{P}$} \\
\hline & $\mathrm{N}$ & $\%$ & $\mathrm{~N}$ & $\%$ & & & & \\
\hline$<35$ & 7 & 3,18 & 40 & 6,15 & $-0,39$ & 6,63 & 3,80 & $\geq 0,05$ \\
\hline $35-70$ & 154 & 70,00 & 597 & 91,85 & $-5,66$ & 3,69 & 1,12 & $<0,05$ \\
\hline$>70$ & 59 & 26,82 & 13 & 2,00 & 3,57 & 5,77 & 3,88 & $<0,05$ \\
\hline \multicolumn{9}{|c|}{ Чоловіки } \\
\hline \multirow{2}{*}{ показник в балах } & \multicolumn{2}{|c|}{ основна група (N=97) } & \multicolumn{2}{|c|}{ порівняльна група (N=268) } & \multirow[t]{2}{*}{$t$} & \multirow[t]{2}{*}{ M1 } & \multirow[t]{2}{*}{ M2 } & \multirow{2}{*}{ P } \\
\hline & $\mathrm{N}$ & $\%$ & $\mathrm{~N}$ & $\%$ & & & & \\
\hline$<35$ & 2 & 2,062 & 10 & 3,73 & $-0,14$ & 10,05 & 5,99 & $\geq 0,05$ \\
\hline $35-70$ & 62 & 63,92 & 254 & 94,8 & $-4,93$ & 6,10 & 1,40 & $<0,05$ \\
\hline$>70$ & 33 & 34,02 & 4 & 1,49 & 3,18 & 8,25 & 6,06 & $<0,05$ \\
\hline
\end{tabular}

Високі показники мали чутливі, сенситивні особи, схильні до тривоги, боязкі, сором'язливі. У справах вони старанні, сумлінні, високоморальні та обов'язкові, але неспроможні прийняти рішення самостійно, не мають впевненості в собі, при найменших невдачах вони впадають у відчай. Особистість легко ідентифікує себе з окремими людьми, явищами, i, якщо це ототожнення порушується, то особистість сприймає це як катастрофу, що призводить до зниження ії настрою. Вже лише сама загроза розриву гармонійних стосунків може викликати у таких осіб тривогу. Тому їх відгородженість - це прагнення уникнути розчарування. Низькі значення свідчать про активність, товариськість, низький рівень тривоги, відчуття своєї значущості, сили, енергії та бадьорості.

Істеричні особливості особистості достовірно частіше були характерними для дівчат з непсихотичними психічними розладами - 16,36 \% та для 13,40 \% хлопців (див. табл. 5). Високі значення за 
Огляди літератури, оригінальні дослідження, погляд на проблему, випадок з практики, короткі повідомлення

Таблиця 5. Показники за шкалою істерії (Ну) СБОО, виявлені у жінок та чоловіків основної та порівняльної груп

\begin{tabular}{|c|c|c|c|c|c|c|c|c|}
\hline \multicolumn{9}{|c|}{ Жінки } \\
\hline \multirow{2}{*}{ показник в балах } & \multicolumn{2}{|c|}{ основна група $(\mathrm{N}=220)$} & \multicolumn{2}{|c|}{ порівняльна група (N=650) } & \multirow{2}{*}{$\mathrm{t}$} & \multirow{2}{*}{ M1 } & \multirow{2}{*}{ M2 } & \multirow{2}{*}{$p$} \\
\hline & $\mathrm{N}$ & $\%$ & $\mathrm{~N}$ & $\%$ & & & & \\
\hline$<35$ & 3 & 1,36 & 40 & 6,15 & $-0,62$ & 6,70 & 3,80 & $\geq 0,05$ \\
\hline $35-70$ & 181 & 82,27 & 605 & 93,08 & $-3,58$ & 2,84 & 1,03 & $<0,05$ \\
\hline$>70$ & 36 & 16,36 & 5 & 0,77 & 2,14 & 6,17 & 3,91 & $<0,05$ \\
\hline \multicolumn{9}{|c|}{ Чоловіки } \\
\hline \multirow{2}{*}{ показник в балах } & \multicolumn{2}{|c|}{ основна група (N=97) } & \multicolumn{2}{|c|}{ порівняльна група (N=268) } & \multirow{2}{*}{$t$} & \multirow{2}{*}{ M1 } & \multirow{2}{*}{ M2 } & \multirow{2}{*}{$p$} \\
\hline & $\mathrm{N}$ & $\%$ & $\mathrm{~N}$ & $\%$ & & & & \\
\hline$<35$ & 2 & 2,062 & 21 & 7,84 & $-0,50$ & 10,05 & 5,86 & $<0,05$ \\
\hline $35-70$ & 82 & 84,54 & 241 & 89,9 & $-1,21$ & 3,99 & 1,94 & $<0,05$ \\
\hline$>70$ & 13 & 13,4 & 6 & 2,24 & 1,00 & 9,45 & 6,04 & $<0,05$ \\
\hline
\end{tabular}

шкалою істерії свідчать про те, що у досліджуваних $є$ схильність до невротичних захисних реакцій конверсійного типу. Вони використовують симптоми соматичного захворювання як засіб уникнення відповідальності. Всі проблеми вирішуються відходом у хворобу. Головною особливістю таких людей є прагнення здаватися більшими, значущішими, ніж вони є насправді, прагнення привернути до себе увагу. Почуття таких людей поверхневі й інтереси неглибокі. Особистість прагне бути в центрі уваги, шукає визнання і підтримки і домагається цього наполегливими діями. Високі показники у істеричних особистостей
( $r=0,323)$ обумовлені наочно-образним типом сприйняття, емоційним забарвленням об'єктів, що сприймаються, що й забезпечує високу продуктивність виконання поставленого завдання. Низьке значення за III шкалою свідчить про інтроверсію, замкнутість, скептицизм, недостатню здатність до спонтанності в соціальних контактах.

Також достовірні відмінності в результатах СБОО у здорових та хворих студентів були виявлені за VI шкалою паранойяльності (Рa), прикметно що високі показники за даною шкалою частіше спостерігалися у жінок (24,09\%), на відміну від чоловіків (19,59 \%) (табл. 6).

Таблиця 6. Показники за шкалою паранояльності (Ра) СБОО, виявлені у жінок та чоловіків основної та порівняльної груп

\begin{tabular}{|c|c|c|c|c|c|c|c|c|}
\hline \multicolumn{9}{|c|}{ Жінки } \\
\hline \multirow{2}{*}{ показник в балах } & \multicolumn{2}{|c|}{ основна група $(\mathrm{N}=220)$} & \multicolumn{2}{|c|}{ порівняльна група (N=650) } & \multirow{2}{*}{$t$} & \multirow{2}{*}{ M1 } & \multirow{2}{*}{ M2 } & \multirow{2}{*}{$p$} \\
\hline & $\mathrm{N}$ & $\%$ & $\mathrm{~N}$ & $\%$ & & & & \\
\hline$<35$ & 12 & 5,45 & 108 & 16,62 & $-1,49$ & 6,56 & 3,58 & $\geq 0,05$ \\
\hline $35-70$ & 155 & 70,45 & 532 & 81,85 & $-2,83$ & 3,66 & 1,67 & $<0,05$ \\
\hline$>70$ & 53 & 24,09 & 10 & 1,54 & 3,20 & 5,87 & 3,89 & $<0,05$ \\
\hline \multicolumn{9}{|c|}{ Чоловіки } \\
\hline \multirow{2}{*}{ показник в балах } & \multicolumn{2}{|c|}{ основна група (N=97) } & \multicolumn{2}{|c|}{ порівняльна група (N=268) } & \multirow{2}{*}{ t } & \multirow{2}{*}{ M1 } & \multirow{2}{*}{ M2 } & \multirow{2}{*}{$p$} \\
\hline & $\mathrm{N}$ & $\%$ & $\mathrm{~N}$ & $\%$ & & & & \\
\hline$<35$ & 4 & 4,124 & 37 & 13,8 & $-0,85$ & 9,94 & 5,67 & $\geq 0,05$ \\
\hline $35-70$ & 74 & 76,29 & 227 & 84,7 & $-1,53$ & 4,94 & 2,39 & $\geq 0,05$ \\
\hline$>70$ & 19 & 19,59 & 4 & 1,49 & 1,65 & 9,10 & 6,06 & $\geq 0,05$ \\
\hline
\end{tabular}

Основна риса людей з високими показниками за шкалою паранояльності - схильність до формування надцінних ідей. Це люди односторонні, агресивні та злопам'ятні. Хто не згоден 3 ними, хто думає інакше, той чи дурна людина, чи ворог. Свої погляди вони активно нав'язують, тому мають часті конфлікти з оточуючими. Власні найменші удачі вони завжди переоцінюють. Низьке значення свідчить про наступні можливі варіанти: 1) досліджуваний недовірливий і обережний, боїться неприємних наслідків своїх дій;
2) у досліджуваного гнучке мислення і він швидко змінює точку зору.

Висновки. У результаті дослідження встановлено, що абсолютні значення за всіма шкалами були вищими у чоловіків з непсихотичними психічними розладами. Достовірно частіше зустрічалися особи обох статей з депресивними, паранояльними, психастенічними та істеричними рисами особистості, що необхідно враховувати при ранній діагностиці та побудові психотерапевтичної програми для даного контингенту хворих. 
Огляди літератури, оригінальні дослідження, погляд на проблему, випадок з практики, короткі повідомлення ЛІТЕРАТУРА

1. Фальова О. Є. Особистість та пізнавальні процеси студентів у ВНЗ: діагностика, розвиток, корекція : навч. посібник для ВН3 / О. Є. Фальова, Є. В. Заїка. Краматорськ, 2005. -402 с.

2. Діагностичні критерії депресивних розладів на етапах надання медичної допомоги / Н. О. Марута, Т. В. Панько, В. Ю. Федченко [та ін.] // Український вісник психоневрології. - 2017. - Т. 25, вип. 1. - С. 135.

3. Моисеева О. Ю. Психодиагностика индивидуальных особенностей личности. Часть 2. Психодиагностика характера : учебно-методическое пособие / О. Ю. Моисеева. - Владивосток: Мор. гос. ун-т, 2007. 253 с. Режим доступа: http://pedlib.ru/Books/5/0226/ 5_0226-1.shtml

4. Чижкова М. Б. Структура личности студентов-первокурсников с разным уровнем адаптации к образовательной среде медицинского вуза / М. Б. Чижкова // Интернет-журнал «Мир науки» - 2017. - Том 5, № 3. - Peжим доступа: http://mir-nauki.com/PDF/29PSMN317.pdf

5. Осипчукова Е. В. Адаптация студентов в учреждениях высшего образования: факторный анализ / Е. В. Осипчукова, Н. В. Попова, Е. В. Попова // Современная высшая школа: инновационный аспект. - 2016. - Т. 8. № 4. - С. 66-74. DOI: 10.7442/2071- 9620-2016-8-4-66-74

6. Собчик Л. Н. Стандартизированный многофакторный метод исследования личности. СМИЛ/Л. Н. Собчик. - СПб. : Речь, 2008. - 219 с.

\title{
REFERENCES
}

1. Falova, O.E., \& Zaika, E.V. (2005). Osobystist ta piznavalni protsesy studentiv u VNZ: diahnostyka, rozvytok, korektsiia: navch. posibnyk dlia VNZ [Personality and cognitive processes of students in universities: diagnosis, development, correction: textbook for universities]. Kramatorsk [in Ukrainian].

2. Maruta, N.O. (2017). Diahnostychni kryteriyi rozladiv na etapakh nadannia medychnoi dopomohy [Diagnostic criteria for depressive disorders in the stages of medical care]. Ukr. Visnyk psykhonevroloh. - Ukrainian Bulletin of Psychoneurology, 25 (1), 135 [in Ukrainian].

3. Moiseeva, O.Yu. (2007). Psikhodiagnostika individualnykh osobennostey lichnosti. Chast 2. Psikhodiagnosika kharaktera: uchebno-metodicheskoye posobiye [Psychodiagnosis of individual personality traits. Part 2. Character psychodiagnostics: A manual]. Vladivostok: State University [in Russian].

4. Chizhkova, M.B. (2017). Struktura lichnosti studentov-pervokursnikov s raznym urovnem adaptatsii k obrazovatelnoy srede meditsinskogo vuza [The personality structure of first-year students with different levels of adaptation to the educational environment of the medical university]. Internet shurnal "Mir nauki" - Internet-Journal "World of Science", 5 (3) [in Russian].

5. Osipchukova, E.V., Popova, N.V., \& Popova, E.V. (2016). Adaptatsiya studentov v ucherezhdeniyakh vysshego obrazovaniya: faktornyy analiz [Adaptation of students in higher education institutions: factor analysis]. Sovremennaya vysshaya shkola: Innovatsionyy aspect - Modern Higher School: Innovative Aspect, 8 (4), 66-74. DOI: 10.7442 / 2071-96202016-8-4-66-74 [in Russian].

6. Sobchik, L.N. (2008). Standartizirovannyy mnogofaktornyy metod issledovaniya lichnosti. SMIL [A standardized method of multivariate study of personality. SMIL]. Saint-Petersburg: Rech [in Russian].

\section{ГЕНДЕРНЫЕ РАЗЛИЧИЯ ЛИЧНОСТНЫХ ОСОБЕННОСТЕЙ СТУДЕНТОВ С НЕПСИХОТИЧЕСКИМИ ПСИХИЧЕСКИМИ РАССТРОЙСТВАМИ}

○О. С. Юрценюк

\author{
ВГУЗ «Буковинский государственный медицинский университет», Черновцы
}

РЕзЮМЕ Проблема специальной диагностики личностных особенностей студентов является актуальной на протяжении всех лет обучения. В статье рассмотрим гендерные различия личностных особенностей и их влияние на формирование непсихотических психических расстройств у студентов.

Цель - изучение гендерных различий личностных особенностей студентов с непсихотическими психическими расстройствами и здоровых студентов.

Материал и методы. В течение 2015-2017 гг. с соблюдением принципов биоэтики и деонтологии мы провели сплошное комплексное обследование 1235 студентов. Использованы клинический, клинико-психопатологический, клинико-эпидемиологический, клинико-анамнестический, экспериментально-психологический и статистический методы. Изучение личностных особенностей проводили с использованием сокращенного многофакторного опросника личности (СМОЛ), разработанного на основании теста MMPI (Minnesota Multiphasic Personality Inventory).

Результаты. Выявлено, что в основной группе наблюдались более высокие абсолютные значения фактически по всем шкалам ( $<<0,005)$. Наивысшие абсолютные показатели у женщин установлены по II (депрессия) и VII (психастения) шкалам - $(59,32 \pm 0,97)$ и $(59,59 \pm 0,96)$ баллов в основной группе $(\mathrm{N}=220)$ и $(44,22 \pm 0,37)$ и 
Огляди літератури, оригінальні дослідження, погляд на проблему, випадок з практики, короткі повідомлення $(46,71 \pm 0,45)$ баллов в сравнительной группе соответственно ( $\mathrm{N}=650)$. У мужчин высокие абсолютные показатели были обнаружены также по II и VII шкалам - $(62,90 \pm 1,56)$ и $(61,58 \pm 1,50)$ баллов в основной группе $(\mathrm{N}=97)$ и $(45,46 \pm 0,52)$ и $(48,17 \pm 0,64)$ балла в сравнительной группе соответственно $(\mathrm{N}=268)$. Истерические особенности личности достоверно чаще были характерны для девушек с непсихотическими психическими расстройствами $16,36 \%$ и для $13,40 \%$ юношей ( $<<0,005)$.

Выводы. Установлено, что среди студентов с непсихотическими психическими расстройствами достоверно чаще встречались лица обеих полов с депрессивными, паранойяльными, психастеническими и истерическими чертами личности, что необходимо учитывать при ранней диагностике и построении психотерапевтической программы для данного контингента больных.

КЛючЕВЫЕ СЛОВА: непсихотические психические расстройства; мини-мульт; студенты.

\section{GENDER DIFFERENCES OF PERSONAL FEATURES OF STUDENTS WITH NONPSYCHOTIC PSYCHIC DISORDERS}

๑O. S. Yurtsenyuk

\section{Bukovynian State Medical University}

SUMMARY. The issue of special diagnostics of student personality features is a topical one during the whole years of studies. The article deals with the effect of gender personality features on the formation of nonpsychotic psychic disorders (NPD) among students.

The aim - to study the gender differences of student's personality features with nonpsychotic psychic disorders among healthy individuals.

Material and Methods. During 2015-2017 keeping to the principles of bioethics and deontology a complete comprehensive examination of 1235 students was performed. The following methods were applied: clinical, clinicalpsychopathologic, clinical-epidemiologic, clinical-anamnestic, experimental-psychological, and statistical. Personality features were studied by means of a condensed version of personality multifactorial questionnaire (CVPMQ) designed on the basis of Minnesota Multiphasic Personality Inventory (MMPI) test.

Results. The conducted study determined that higher absolute values were found practically by all the scales $(p<0.005)$ in the main group (students with NPD). The highest absolute scores for women were set on the II (depression) and VII (psychasthenia) scales - (59.32 \pm 0.97$)$ and $(59.59 \pm 0.96)$ in the main group $(\mathrm{N}=220)$ and $(44.22 \pm 0.37)$, respectively; and $(46.71 \pm 0.45)$ points in the comparison group, respectively $(\mathrm{N}=650)$. In men, the highest absolute values were also found on II and VII scales - $(62.90 \pm 1.56)$ and $(61.58 \pm 1.50)$ points in the main group $(\mathrm{N}=97)$ and $(45.46 \pm 0.52)$ and $(48.17 \pm 0.64)$ points in the comparison group, respectively $(\mathrm{N}=268)$. Hysterical personality traits were significantly more common in girls with non-psychotic psychiatric disorders ( $16.36 \%$ and $13.40 \%)(p<0.005)$.

Conclusions. Individuals with depressive, paranoiac, psychasthenic and hysterical personality features were found reliably more often among students both sexes with nonpsychotic psychic disorders. It should be considered in early diagnostics and making psychotherapeutic program for this group of patients.

KEY WORDS: nonpsychotic psychic disorders; mini-mult; students. 